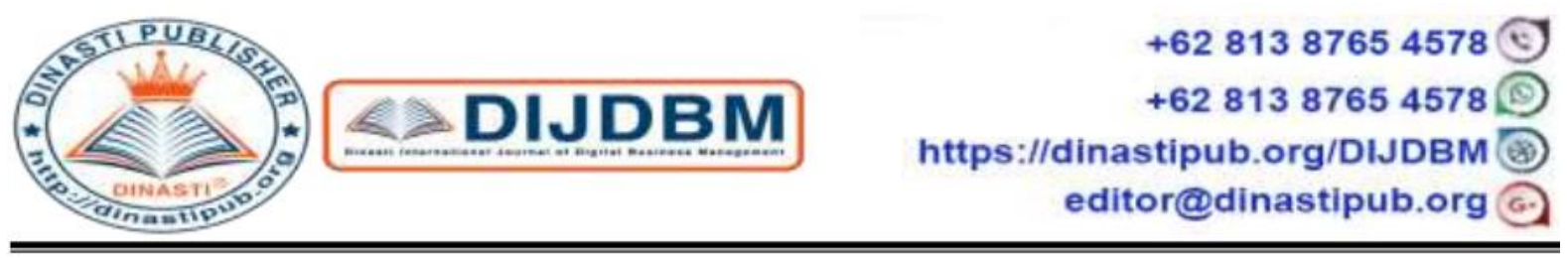

\title{
THE EFFECT OF TANSFORMATIONAL, TRANSACTIONAL, AUTHENTIC AND AUTHORITARIAN LEADERSHIP STYLE TOWARD LECTURE PERFORMANCE OF PRIVATE UNIVERSITY IN TANGERANG
}

\author{
Agus Purwanto'), Laksmi Mayesti Wijayanti²), Choi Chi Hyun ${ }^{3)}$, Masduki Asbari ${ }^{4)}$ \\ 1,2,3,4)Universitas Pelita Harapan, Tangerang, Indonesia
}

\begin{tabular}{|l|l|}
\hline ARTICLE INFORMATION & $\begin{array}{l}\text { Abstract: The aim of this study is to analyze the effect of } \\
\text { Received: 26 December 2019 } \\
\text { transformational, transactional, authentic and authoritarian } \\
\text { Revised: 31 December 2019 } \\
\text { lssued: 7 January 2020 }\end{array}$ \\
$\begin{array}{l}\text { Corresponding author: } \\
\text { university in Tangerang. The study population are lecture of } \\
\text { private university as many as 120 lectures from 14 of private } \\
\text { university and data collection methods by giving an electronics } \\
\text { Euestionnaire to the lectures of private university in Tangerang. } \\
\text { The data analysis tool of this study uses SEM (Structural } \\
\text { Equation Model) the LISREL program version 8.70. The } \\
\text { results show that the transformational, transactional and } \\
\text { authorian leadership style have positive and significant } \\
\text { affected to lecture performance. Transformational leadership } \\
\text { and authentic leadership has no significant effect to lecture } \\
\text { performance. }\end{array}$ \\
$\begin{array}{l}\text { Keywords: Transformational, Transactional, Authentic and } \\
\text { Authoritarian Leadership Style, Lecture Performance }\end{array}$ \\
\hline
\end{tabular}

\section{INTRODUCTION}

Several previous studies began the topic of leadership style influence on the performance of that Dwiantoro et al.(2017) has been observed that the type of leadership style transformational significant positive effect on performance, transactional leadership style type significant adverse effect on performance. Lengkong et al. (2018) examines the impact of transformational leadership on employee performance, and transactional leadership does not affect the performance of employees. Ong et al (2018) conducted research and concluded that the effect of transformational leadership style on performance. Transactional leadership style does not affect performance. Aqmarina et a (2016)] conducted research and concluded that the type of transformational leadership negatively and not significantly influence employee performance transactional leadership while no significant influence on employee performance. Wahyuniardi et al (2018) conducted research and concluded that the type of transformational leadership has a significant effect on job satisfaction, the kind of transformational leadership has no significant influence on employee performance, organizational culture has no significant impact on employee performance, and job satisfaction did not significantly affect the 
performance of the employee. To improve employee performance can be done by increasing job satisfaction if job satisfaction increases, the performance of employees will also increase. Birasnav et al (2014) has also researched leadership and research results show that the type of transformational leadership and transactional models have a strong and positive effect on organizational performance after controlling for the impact of transactional leadership.

Al-Musadieq et al ( 2017) in the previous study stated that the influence of the organizational factors of job design on the upgrading of staff performance evidenced to be significant with the motivating aspect of work motivation the study also found in the indirect practical relationship between organizational culture and intervening variables of work motivation. Rivai, et al.(2018) however stated that a leader can be considered as a successful a leader if based on the measurement he is able to influence and develop those whom he leads. The good traits of a leader is caring and being sensitive to the needs of the people he leads that the subordinates are approachable and willing to discuss their dreams and hope.There are some kinds of model of leadership that are apparent in any organization, some are very influential. This study is conducted to see which kind of leadership that is highly effective to influence the lecture performance will bring significant impact on the performance of all lecture. In regard to the various models of leadership, this study is examining whether transformational leadership, transcational leadership, authentic leadership or authoritarian leadership would have significantly influenced the lecture performance at private university in Tangerang.

Salbiyah et al. (2019) state that as mandated in Law Number 14 of 2005 concerning teachers and lecturers, lecturers are declared as professional educators and scientists with the main task of transforming, developing and disseminating science, technology, and art through education, research, and community service (Chapter 1 Article 1 paragraph 2). The main task of the lecturer is to carry out tri dharma of higher education witha workload of at least 12 (twelve) credits and a maximum of 16 (six)twelve) credits in each semester according to academic qualifications. The implementation of the main tasks of this lecturer needs to be evaluated and reported periodically as a form of accountability of lecturers' performance to the stakeholders (Dirjen Dikti, 2010: 1).

The aim of this study is to analyze the effect of transformational, transactional, authentic and authoritarian leadership styles toward lecture peformance in some private university in Tangerang.

The purpose of this research is:

1. Test and analyze the effect of transformational leadership toward the lecture performance.

2. Test and analyze the effect of transactional leadership toward the lecture performance.

3. Test and analyze the effect of authentic leadership toward the lecture performance.

4. Test and analyze the effect of authoritarian leadership toward the lecture performance.

\section{LITERATURE REVIEW}

\section{Leadership}

Veithzal Rivai, et al.(2018) state that the word leadership is the ability to influence people's behaviors to achieve certain goal in a particular situation. Leadership always correlate with social concerns that means there is interaction between the leaders with those he leads to accomplish the same purpose and target.

\section{Transformational Leadership}


Bass (1998) stated four transformational components: idealized influence transformational leaders conduct their lives to be admired, respected and trusted by their followers; inspirational motivation transformational leaders motivate and inspire those around them by offering meaning, optimism and enthusiasm for a vision of a future condition; intellectual stimulation: transformational leaders foster followers be creative and innovative to solve problems in new ways and to not to make assumptions; individualized consideration transformational leaders actively cultivate the potential of their followers by generating new chances for development and consistently coaching, mentoring, and paying attention to the needs and desires of the followers, rather than monitoring their efforts. Leithwood (20040 state that 1 transformational style to leadership underscore emotions and norms then mutually share the basic goal to nurture the capacity progress and advanced level of one's commitment toward the organization's objectives. Erkutlu et al (2008) compared transformational leadership with transactional leadership and stated that transformational leadership outcomes in accomplishment that exceed what is anticipated. Lowe et.al (1996) confirmed that in a metaanalysis of 39 studies discovered that individuals who demonstrated transformational leadership were distinguished to be more effective leaders with better work products than those who demonstrated only transactional leadership.Krishnan (2002) also initiated transformational leadership style is certainly linked to serious value correspondence between the leader and devotee.

Yukl (2010) explains that Transformational leadership calls for moral values from followers in their efforts to increase their awareness of ethical issues and to mobilize their energy and resources to reform institutions. According to Bass (1996) Transformational leadership is defined as a leader who has the power to influence his subordinates in certain ways, Transformational leadership is defined as a leader strengthening mutual cooperation and team learning. Meanwhile, according to O'Leary (2001) Transformational leadership is a leadership style used by a manager if he wants a group to widen its boundaries and have performance beyond the status quo or achieve an entirely new set of organizational goals. Transformational leaders can successfully change the status quo in their organizations by practicing appropriate behavior at each stage of the transformation process. Bass (1985) states that transformational leadership is leadership that goes beyond mere exchange or reward for performance displayed by followers but is based more on trust and commitment (Jung and Avolio, 1999). Transformational leaders pay attention to the development needs of each of the followers and problems by helping them see old problems in new ways, and they are able to motivate, nurture, excite, awaken, and inspire followers to make extra efforts to achieve group goals. This transformational leadership is truly called true leadership because this leadership really works towards goals that lead the organization to a goal that is never achieved previously (Locke 1997) With transformational leadership, subordinates will feel trusted, valued and subordinates will appreciate their leaders more.

According to Bass (1990) explains about the dimensions of transformational leadership, suach as Charisma is the ability of leaders to arouse pride, trust and respect for their subordinates and is able to effectively communicate the mission and vision of the organization they lead.Inspirational, describes the extent to which a leader communicates an interesting vision, uses symbols to focus the efforts of subordinates and express important goals in a simple way'.Intellectual stimulation, is the behavior of leaders who encourage their subordinates to always innovate and be creative in solving the problems they are facing, offering new ideas to stimulate their subordinates to rethink old ways of completing work and influence subordinates 
to look at problems - problems from a new perspective. Individualized consideration, is the behavior of leaders who always care about the development of the abilities of their subordinates, treat subordinates as individuals, try to understand the desires of subordinates and function as advisors.

\section{Transactional Leadership Style}

The definition of transactional leadership is inseparable from Burn (1978), namely leadership which deals with motivating followers by calling on their personal interests (Yukl 2010: 290). According to Yukl (2010: 291) transactional leadership can involve values, but those values are relevant to exchange processes such as honesty, responsibility, and reciprocity. Bas (in Yukl 1998: 125) suggests that the relationship of transactional leaders with their subordinates is reflected in three things, The leader knows what the subordinates want and will explain what the subordinates will get if the work is in line with expectations. The leader exchanges the efforts made by subordinates in return. Leaders are responsive to the personal interests of subordinates as long as those interests are proportional to the value of the work done by subordinates.

Bass (1985) also argues that the characteristics of transactional leadership consist of two aspects, contingent rewards is the leader informs his subordinates about what their subordinates must do if they want to get certain rewards and guarantees that the subordinates will get what they want in lieu of the effort done. Exception management is the leader trying to maintain the achievements and workings of his subordinates, if there is a mistake the leader immediately acts to correct it.

\section{Authentic Leadership}

Besides the transformational leadership another great type of leadership is authentic leadership. Kernis et al (2003) stated, that authentic leadership similar to the transformational type, has also four dimensions. Self-awareness has multilayered nature of the self that contains finding insight into the self through exposure to others and being acquainted with the impact on other, in other words self-awareness is pointed out by showing an understanding of everyone's potency and limitations. Relational transparency is the second dimension that presents authentic self to others by creating trust through openness which means willing to share the deepest emotions and thoughts while lessening improper reactions and manners. Balanced processing associates with leaders who always analyze all significant data factually before making any decision, they request notions that assessment intensely held(Walumbwa et al , 2007). The last one is internalized moral perspective, as it is, it refers to an affected and assimilated form of self-regulation guided by internal ethical standardsand principles. And the outcome of decision -making and behavior consistent with these internalizes principles.

Alavi et al (2018) stated that authentic leadership (Avolions et al, 2004; Gardner et al, 2011 ) has aptitudes, particularlyfor multifaceted adjustment of an organization due to the efficiencyto bring changes with several methods in the developments oforganizations. Further, according to Avolio et al (2004), authentic leaders haveaccomplished high levels of authenticity in their self-identity that they applied their strong conviction of set of values while evidently intermingling with others. It stated that authentic leadershipstimulates several motivational and learning ways in followers during the change process, which assist the effective execution of change. (Alaviand Gill, 2018). Authenticity means 'know yourself' was initiated from an ancient Greek philosopher Socrates thatis with individualized experience, including self-perception of his own views, moods, wishes, inclinations, and theories (Snyder and Lopez, 2009). The purpose of this study is to discover the competence of authentic leadership in comparison to transformational leadership and authoritarian leadership toward 
the culture of organization, the motivation of the workers to bring out the result in the performance of the workers.

\section{Authoritarian Leadership}

It refers to a leader's conduct of declaring strong authority and regulate coworkers and challenging unquestionable submission from them (Farh et al, 2000). Muhumuza, (2015), defined the authoritarian leadership as a leadership style characterized by the leader preserving as much power and decision-making authority as possible. The leaders have composed a collection of rewards and punishments and operated threats and punishment to control inferiors, whose idea almost never been heard. Zylfijaj et.al, (2014) stated that authoritarian leadership style will not motivate the subordinates, and demand the job accomplished promptly. These leaders are believed to be controllers that the subordinates just need to bring the outcome based on the leader's specifications. Frequently, the authoritarian leader came up with solution that was not too inventive, therefore it would have lowered the follower's devotion toward the chores (Lazar, 2006). Confirmed by Li-Chuan Chu, 2014 stated the prior studies indicated that supervisors' authoritarian behavior aroused negative. There are four significant aspects according to Cheng (1993, 1995) and Farh and Cheng (2000), These are (1) authority and control, means that unwilling to delegate, involve in only top-down interaction, control data so that it is doubtful, and fussily monitor juniors, (2) look down on the subordinate competence, therefore will not hear the subordinates' ideas and inputs, (3) image building, which makes the leaders to reserve their own self-respect confidently to manipulate associated notes and (4) didactic behavior, which means some demands on specific achievement and conduct and if it failed, harsh reprimands and scolds occurred that would generate negative emotions in subordinates, such as wrath, aggression, and anxiety (Farh et al., 2006; Wilkinson, 1996; Wu et al., (2003), (Leonard,2018; Men, 2010). The circumstances could be used pronounced Cherry (2018) when there are some untrained staff who confuse how to perform or which techniques to follow then some strong yet effective directions can be delivered through details.

\section{Lecturer Performance}

Salbiyah et al ( 2019 ) state that with regard to the performance and responsibilities of lecturers in carrying out their professional duties, the performance of lecturers through the duties and responsibilities of lecturers is contained in Law No. 14 of 2005, namely: (1) Carry out education, research, and community service, (2) Plan, implement the learning process, and assess and evaluate learning outcomes; (3) Continuously increasing and developing academic qualifications and competencies; (4) Acting objectively and not discriminatory on the basis of consideration of gender, religion, ethnicity, race, specific physical conditions, or socioeconomic background of students in learning; (5) Upholding the statutory regulations, laws and codes of ethics, as well as religious and ethical values; and (6) maintaining and fostering national unity and integrity.

According to the Director-General of Higher Education (2010: 7), lecturers have the following main tasks. The task of conducting education is a task in the field of education and teaching, including conduct lectures/tutorials and test and organize educational activities in laboratories, teacher practices, workshop practices/studios/ experimental gardens/teaching technology,guiding student seminars, guiding real work lectures $(\mathrm{KKN})$, real work practices (PKN), fieldwork practices (PKL), guiding the final project of student research including guiding, making a final report of the research results, examiners on the final exam, fostering student activities in the academic and student fields, developing lecture programs, developing teaching materials,. delivering scientific speeches,fostering student activities in the academic 
and student fields. guiding lower level lecturers, carry out lecturer training and transplant activities ( Salbiyah, 2019).

Salbiyah et al.(2019) state that the task of conducting research is a task in the field of research and development of scientific work, including producing research work, translating or adapting scientific books, editingscientific papers, making design and technology works, creating a design of art (DirjenDikti, 2010: 7). The task of doing community service includes occupying leadership positions in government agencies/state officials so they must be released from their organic positions, carry out the development of educational and research results that can be utilized by the community,providing training/counseling/ upgrading to the community, providing services to the community or other activities that support the implementation of general government and development tasks, making and writing community service (DirjenDikti, 2010: 7). The duties of supporting the three-tri dharma of higher education include become a member of a committee/body in higher education, become a member of the committee/body in a government institution, become a member of a professional organization, representing a tertiary institution/government institution sitting on an inter-institutional committee, become a member of a national delegation to an international meeting, participating in and active in scientific meetings, get a service award,award, writing high school textbooks down, having achievements in the field of sports, arts, social (Director General of Higher Education, 2010: 8).

\section{RESEARCH METHODS}

Data analysis of this research using the Structural Equation Model (SEM) using a Linear Structural Model (LISREL) version 8.70. data collection methods by giving an electronics questionnaire to the lectures. The study population are lecture of private university as many as 120 lectures from 14 of private university.

Table 1. Profile of Lecture Respondents

\begin{tabular}{|c|c|c|c|}
\hline $\begin{array}{c}\text { Academic } \\
\text { Functional Position }\end{array}$ & Man & Woman & Total \\
\hline Staf Pengajar & 20 & 10 & 30 \\
\hline Asisten Ahli & 25 & 15 & 40 \\
\hline Lektor & 27 & 13 & 40 \\
\hline Lektor Kepala & 8 & 2 & 10 \\
\hline
\end{tabular}

Note : The respondent profile table is derived from a summary of the questionnaire returned (authors, 2019)

Based on the previous studies and the AIM of writing this study, it will be created a research model as follows: 


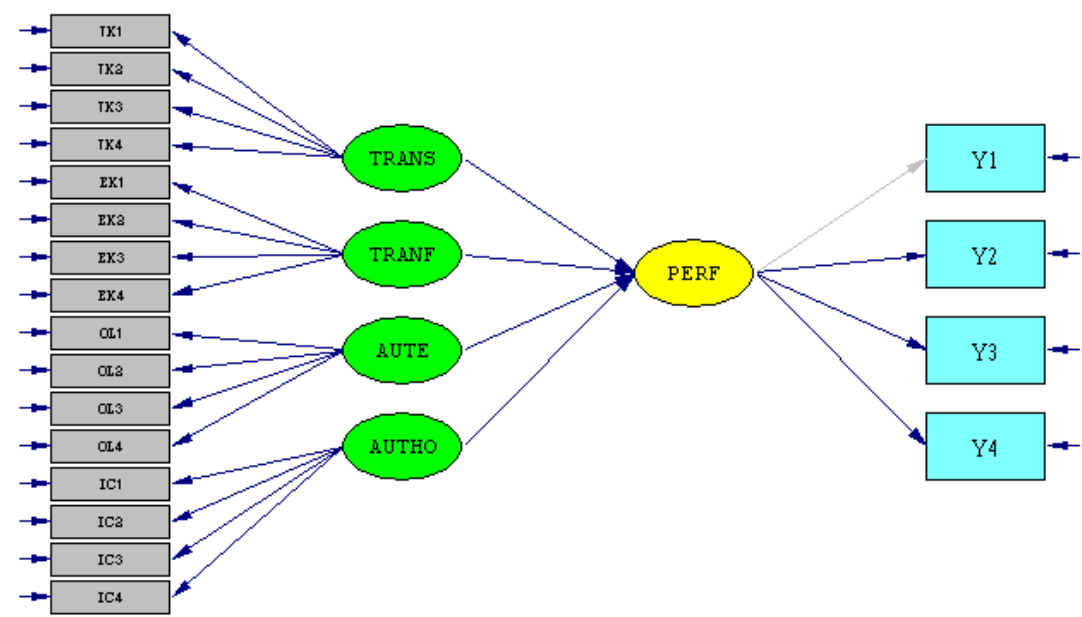

Figure 1. Model of Research

Note : The figure 1 is derived from the output of the Lisrel program (authors, 2019) Based on the above research model will be made the following hypotheses:

1. H1 : There is a significant rrelationship between Transactional Leadership (TRANS) to the Lecture Performance (PERF).

2. H2 : There is a significant rrelationship between Transformational Leadership (TRANS) to the Lecture Performance (PERF).

3. H3 : There is a significant relationship between Authentic Leadership (TRANS) to the Lecture Performance (PERF).

4. $\mathrm{H} 4$ : There is a significant rrelationship between Authoritarian Leadership (TRANS) to the Lecture Performance (PERF).

The distribution of electronic questionnaire data from November until Desember 2019 in private university in Tangerang.

\section{FINDINGS AND DISCUSSION}

The first step is to create a syntax program on Lisrell software after that the program is run to get the loading factor of Transactional Leadership (TRANS),Transformational Leadership (TRANS), Authentic Leadership (TRANS), Authoritarian Leadership (TRANS) and Lecture Performance (PERF). Data analysis is conducted by Structural Equation Model (SEM) using a Linear Structural Model (LISREL) version 8.70 of Joreskog and Sorbom (2008), and the results are in the following figure.: 


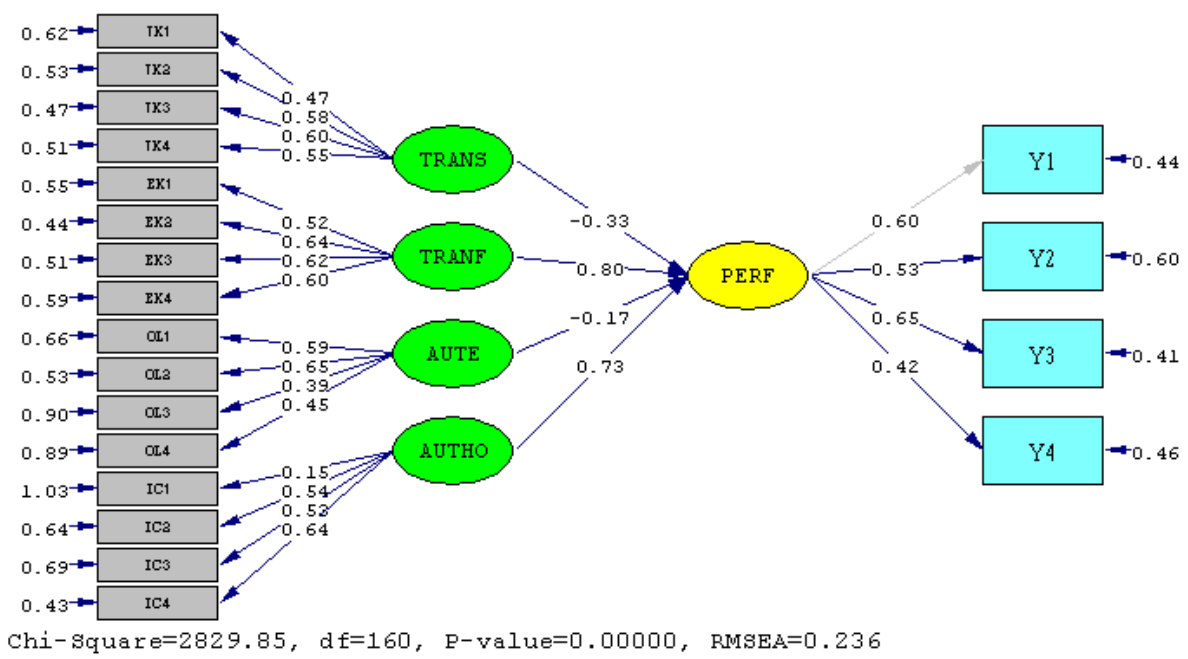

Figure 2. Loading factor Value Indicator

Note : The figure comes from the output of the Lisrel program processing (authors, 2019)

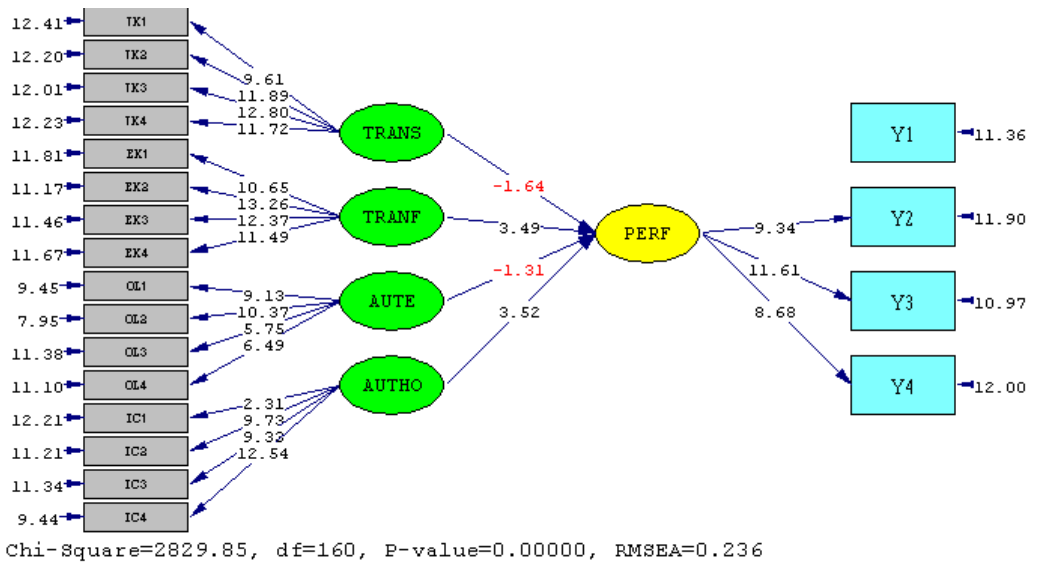

Figure 3. t-Value Indicator

Note : The figure comes from the output of the Lisrel program processing (authors, 2019)

Based on figure 2 and figure 3 is concluded that no error variance negative value, and the value of the indicator Transactional Leadership (TRANS),Transformational Leadership (TRANS), Authentic Leadership (TRANS), Authoritarian Leadership (TRANS) and Lecture Performance (PERF) above the loading factor of $0.5(>0.5)$ Then the results of the output lisrell of each indicator and loading factor are summarized in the table for analysis of validity and reliability ummary of the results of the analysis can be seen in the following table:

Table 2. Results of 2nd Order Analysis Indicators CFA Construct Validity 


\begin{tabular}{|c|c|c|c|c|}
\hline Variable & Indicator & $\begin{array}{l}\text { Loading } \\
\text { Factor }\end{array}$ & $\begin{array}{c}T- \\
\text { Value }\end{array}$ & Remark \\
\hline \multirow{4}{*}{$\begin{array}{l}\text { Transactional } \\
\text { Leadership ( } \\
\text { TRANS) }\end{array}$} & TRANS 1 & 0.47 & 9.61 & Valid \& Sig \\
\hline & TRANS 2 & 0.58 & 11.89 & Valid \& Sig \\
\hline & TRANS 3 & 0.60 & 12.80 & Valid \& Sig \\
\hline & TRANS 4 & 0.65 & 11.72 & Valid \& Sig \\
\hline \multirow{4}{*}{$\begin{array}{l}\text { Transformational } \\
\text { Leadership } \\
\text { (TRANF) }\end{array}$} & TRANF 1 & 0.52 & 10.65 & Valid \& Sig \\
\hline & TRANF 2 & 0.64 & 13.26 & Valid \& Sig \\
\hline & TRANF 3 & 0.62 & 12.37 & Valid \& Sig \\
\hline & TRANF 4 & 0.60 & 11.49 & Valid \& Sig \\
\hline \multirow{4}{*}{$\begin{array}{l}\text { Authentic } \\
\text { Leadership ( } \\
\text { AUTE) }\end{array}$} & AUTE 1 & 0.59 & 9.13 & Valid \& Sig \\
\hline & AUTE 2 & 0.65 & 10.37 & Valid \& Sig \\
\hline & AUTE 3 & 0.39 & 5.75 & Valid \& Sig \\
\hline & AUTE 4 & 0.45 & 6.49 & Valid \& Sig \\
\hline \multirow{4}{*}{$\begin{array}{l}\text { Authoritarian } \\
\text { Leadership } \\
\text { (AUTHO) }\end{array}$} & AUTHO 1 & 0.55 & 2.31 & Valid \& Sig \\
\hline & AUTHO 2 & 0.54 & 9.73 & Valid \& Sig \\
\hline & AUTHO 3 & 0.53 & 9.32 & Valid \& Sig \\
\hline & AUTHO 4 & 0.64 & 12.54 & Valid \& Sig \\
\hline
\end{tabular}

Note The table comes from the output of the Lisrel program processing (authors, 2019) Based on the above test results showed that the value of the loading factor is obtained entirely above 0.5 (>0.5), and all the $t$ value obtained is more significant than 1.96 (> 1.96). A summary of the results of the above analyses can be seen in Table 3 .

Table 3. Analysis For the 2nd Order CFA OCB Construct Validity

\begin{tabular}{|l|l|l|l|}
\hline Variable & $\begin{array}{c}\text { Loading } \\
\text { Factor }\end{array}$ & T-Value & Remark \\
\hline Transactional Leadership & -0.33 & -1.64 & No Significant \\
Transformational & 0.80 & 3.49 & Significant \\
Leadership & -0.17 & -1.31 & No Significant \\
Authentic Leadership & 0.73 & 3.52 & Significant \\
Authoritarian Leadership & & & \\
\hline
\end{tabular}

Note : Table comes from the output of the Lisrel program processing (authors, 2019)

These results can be concluded that transactional leadership has not significant effect to lecture performance, transformational leadership has significant effect to lecture performance, authentic leadership has not significant effect to lecture performance, authoritarian leadership has significant effect to lecture performance.

Table 4. Results of 2nd Order Analysis Construct Reliability. 


\begin{tabular}{|c|c|c|c|c|}
\hline Indicator & $\begin{array}{l}\text { Loading } \\
\text { Factor } 2\end{array}$ & $\begin{array}{l}\text { 1-Loading } \\
\text { Factor2 }\end{array}$ & $C R$ & VE \\
\hline TRANS 1 & 0.47 & 0.58 & \multirow{20}{*}{0.76} & \multirow{20}{*}{0.63} \\
\hline TRANS 2 & 0.58 & 0.69 & & \\
\hline TRANS 3 & 0.60 & 0.62 & & \\
\hline TRANS 4 & 0.65 & 0.85 & & \\
\hline TRANF 1 & 0.52 & 0.95 & & \\
\hline TRANF 2 & 0.64 & 0.39 & & \\
\hline TRANF 3 & 0.62 & 0.42 & & \\
\hline TRANF 4 & 0.60 & 0.31 & & \\
\hline AUTE 1 & 0.59 & 0.36 & & \\
\hline AUTE 2 & 0.65 & 0.44 & & \\
\hline AUTE 3 & 0.39 & 0.45 & & \\
\hline AUTE 4 & 0.45 & 0.46 & & \\
\hline AUTHO 1 & 0.55 & 0.57 & & \\
\hline AUTHO 2 & 0.54 & 0.46 & & \\
\hline AUTHO 3 & 0.53 & 0.47 & & \\
\hline AUTHO 4 & 0.64 & 0.56 & & \\
\hline PERF 1 & 0.47 & 0.48 & & \\
\hline PERF 2 & 0.58 & 0.49 & & \\
\hline PERF 3 & 0.60 & 0.56 & & \\
\hline PERF 4 & 0.65 & 0.54 & & \\
\hline
\end{tabular}

Note : Table comes from the output of the Lisrel program processing (authors, 2019)

Based on the calculation formula $\mathrm{CR}$ construct reliability was obtained results and indicators $\mathrm{VE}$ is $0.76(\mathrm{CR}) \geq 0.70$ and $0.63(\mathrm{VE}) \geq 0.50$. and concluded that the variable good reliability and value constructs have good reliability. Therefore, based on the results of the analysis of the reliability calculation can be concluded that the reliability of the whole is a good indicator and conclude that the research meets the requirements of all phases of testing. The next step is to carry out the Analysis of Goodness of Fit (GOF), GOF data obtained from the results of the software execution

Analysis Goodness Of Fit (GOF) 
Test the suitability of the model in the overall model fit about the analysis of statistical GOF value generated by the program lisrel, for the relevance of the model (model fit) are good enough and for its model fit the criteria as shown in Table 5.

Tabel 5. Goodness Of Fit

\begin{tabular}{|l|l|l|l|}
\hline Indeks Fit & Value & Value Standard & Remark \\
\hline Chi-Square & 80.19 & $>0.5$ & Fit \\
\hline $\begin{array}{l}\text { Root Mean Square Error of } \\
\text { Approximation (RMSEA) }\end{array}$ & 0.05 & $<0.08$ & Fit \\
\hline Normed Fit Index (NFI) & 0.91 & $>0.90$ & Fit \\
\hline Non-Normed Fit Index (NNFI) & 0.92 & $>0.90$ & Fit \\
\hline Comparative Fit Index (CFI) & 0.92 & $>0.90$ & Fit \\
\hline Incremental Fit Index (IFI) & 0.91 & $>0.90$ & Fit \\
\hline Relative Fit Index (RFI) & 0.91 & $>0.90$ & Fit \\
\hline Goodness of Fit Index (GFI) & 0.91 & $>0.90$ & Fit \\
\hline
\end{tabular}

Note : Table comes from the output of the Lisrel program processing (authors, 2019)

Based on the results of the analysis above can be seen that all fit indices stated that the model fit. These results indicate that the variable is declared valid and reliable so that it can be concluded that the overall model is still a good match. Model equation (Structural Equations) linear from 8.70 LISREL software obtained as follows:

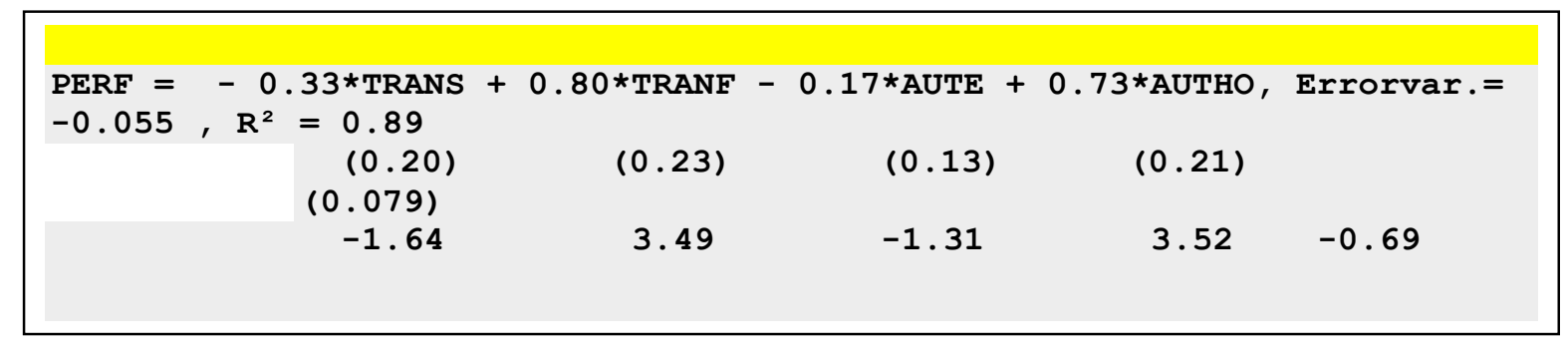

Figure 4. Structural Equations 2019)

Note : The figure comes from the output of the Lisrel program processing (authors,

Based on the results from all the above analysis, it can summarized and obtained the following regression equation (Lecture Performance) $=-0.33^{*}$ TRANS $+0.80 *$ TRANF $0.17 *$ AUTE $+0.73 *$ AUTHO, Errorvar. $=-0.055$

\section{CONCLUSION AND SUGGESTION}

Based on the analysis of the results of research can be concluded that there is a not significant effect Transactional Leadership (TRANS) to the Lecture Performance (PERF), There is no significant effect Transformational Leadership (TRANS) to the Lecture Performance (PERF). There is no significant effect Authentic Leadership (TRANS) to the Lecture Performance (PERF).There is significant effect between Authoritarian Leadership (TRANS) to the Lecture Performance (PERF). Purwanto et al.(2019) conducted study and conclude that transformationasil and transactional leadership has positive and significant 
effect to business performance. Asbari et al (2019) state that transformational effect also have significant effect to work performance.Mirayani et al (2019) authentic and athoritarian leadership has significant effect to work performance.

\section{LIMITATION}

This study has several limitations, the sample not representative of the target population, the number of samples that are not much due to limited time and cost, the object of this study is only lecture in private university. The limited time of the study and the number of respondents who only 120 people have not convinced to generalize the results of research. Software used for data analysis is Lisrel and a lot of people not yet familiar with this software. For next study can expand the respondent in goverment university and in other place.

\section{REFERENCE}

Alavi,Seyyed Babak and Gill, Carol, (2016). Leading Change Authentically: How Authentic Leaders Influence Follower Responses to Complex Change. ournal of Leadership \& Organizational Studies, Issue DOI: 10.1177/1548051816664681, pp. 1- 15.

Al-Musadieq, Muhammad, Nurjannah, Raharjo, Kusdi,Solimun and Fernandes, Adji Achmad Rinaldo, (2018). "The mediating effect of work motivation on the influence of job design and organizational. Journal of Management Development, 10( Emerald Publishing Limited). Anon., n.d. Beverly AlimoMetcalfe and Robert J. Alban-Metcalfe, 2001. The development of a new Transformational Leadership Questionnaire. Journal of Occupational and Organizational Psychology, 74(The British Psychological Society), pp. 1-27.

Asbari, M., Santoso, P., \& Purwanto, A. (2019). Pengaruh Kepemimpinan dan Budaya Organisasi Terhadap Perilaku Kerja Inovatif Pada Industri 4.0. JIM UPB (Jurnal Ilmiah Manajemen Universitas Putera Batam), 8(1), 7-15. doi: https://doi.org/10.33884/jimupb.v8i1.1562

Asbari, M., Santoso, P., \& Purwanto, A. (2019). Pengaruh Iklim Organisasi dan Kepemimpinan Transformasional Terhadap Produktivitas Kerja Inovatif Pada Industri Manufaktur di Pati Jawa Tengah. Jurnal Produktivitas Universitas Muhammadiyah Pontianak, 7(1 2020), 62-69. doi: DOI : 10.29406/jpr.v7i1.1797

Bosch, D., (2013). The Impact of Transformational Leadership on Leader-Follower Work Value Congruence. International Journal of Business and Social Research (IJBSR), Volume vol. 3 no 8, pp. $18-31$.

Chukwusa, J., (2019). Autocratic Leadership Style: Obstacle to Success in Academic Libraries. Library Philosophy and Practice e-Journal, Issue DigitalCommons@University of Nebraska - Lincoln. Chu, L.-C., 2013. The moderating role of authoritarian leadership on the relationship between the internalization of emotional regulation and the well-being of employees. Leadership, Issue DOI: 10.1177/1742715013498403, p. 1-18.

Corbin, B., (2000). Entrepreneurial Leadership: Fundamentals. Carmel: Corbin Group Publishing. Erkutlu, H., 2008. The impact of transformational leadership on organizational and leadership effectiveness. Journal of Management Development, Vol. 27 (No. 7), pp. 708-726. 
Fachreza, Said Musnadi, M. Shabri Abd Majid, (2018). Pegaruh Motivasi kerja,Lingkungan Kerja,Dan Budaya Organisasi Terhadap Kinerja Karyawan Dan Dampaknya Pada Kinerja Bank. jurnal Magister Manajemen ISSN 2302-0199.

Fadhil, Achmar dan Mayowan, Yuniadi, (2018). Pengaruh Motovasi Kerja dan Kepuasan Kerja Terhadap Kinerja Karyawan AJB Bumiputra. Jurnal (JAB), vol 54 (no 1).

Mirayani, R., S.Williana Kusumaningsih, \& Anggaripeni Mustikasiwi. (2019). TRANSFORMATIONAL, AUTHENTIC, AND AUTHORITARIAN TYPES OF LEADERSHIP: WHICH ONE IS THE MOST INFLUENTIAL IN STAFFS' PERFORMANCE (A Study On Performance In A Religious School Setting). Dinasti International Journal of Education Management And Social Science, 1(2), 172-182. https://doi.org/10.31933/dijemss.v1i2.68

Firdaus, R.A.,Purnamasari, D., Akuba, S.F.(2019) The influence of motivation, leadership and perceived workload as intervening on teacher commitment. Journal of Education and Science Technology, 5(3) . DOI : https://doi.org/10.26858/est.v5i3.10847

Kotzé, Martina and Nel, Petrus, (2017). Personal factor effects on authentic leadership. Journal of Psychology in Africa, Vol. 27, No. 1(Africa Scholarship Development Enterprize), p. 47-53.

Lee, C. S., (2018). Authentic Leadership and Organizational Effectiveness: The Roles of Hope, Grit, and Growth Mindset. International Journal of Pure and Applied Mathematic, Volume 118 no 19(Special), pp. 383-401.

Mboya,Millicent Atieno, Were,Susan and Otieno,Romanus Odhiambo , Month: October 2017 - March 2018. EFFECT OF AUTOCRATIC LEADERSHIP STYLE ON QUALITY ASSURANCE IN INSTITUTIONS OF HIGHER LEARNING IN KENYA. International Journal of Management and Commerce Innovations, Volume Vol. 5, Issue 2, pp. 1214-1225.

MUHUMUZA, M. V., 2015. THE INFLUENCE OF AUTHORITARIAN LEADERSHIP ON SOCIAL, POLITICAL AND ECONOMIC DEVELOPMENT: A COMPARATIVE STUDY OF ZAMBIA AND SINGAPORE, s.l.: TECHNICAL UNIVERSITY OF KENYA.

Purwanto, A., Asbari, M., \& Santoso, P.(2019). Does Culture, Motivation, Competence, Leadership,Commitment Influence Quality Performance?. Jurnal Inovasi Bisnis, 6(2), 201-205. DOI: https://doi.org/10.35314/inovbiz.v7i2.1210

Purwanto, A., Asbari, M., \& Santoso, P.(2019).Influence of Transformational and Transactional Leadership Style toward Food Safety Management System ISO 22000:2018 Performance of Food Industry in Pati Central Java. Jurnal Inovasi Bisnis, 6(2), 180-185. DOI: https://doi.org/10.35314/inovbiz.v7i2.1213

Purwanto, A., Asbari, M., \& Santoso, P.(2019).Pengaruh Kompetensi, Motivasi, Kepemimpinan, Komitmen dan Budaya Kerja Sistem Manajemen Integrasi ISO 9001, ISO 14000 dan ISO 45001 Pada Industri Otomotif. Jurnal Produktivitas Universitas Muhammadiyah Pontianak, 6(2),158-166. DOI: http://dx.doi.org/10.29406/jpr.v6i2.1798

Siti Salbiyah, Fitri Nuraini, Asyidatur Rosmaniar ( 2019 ). Motivation And Its Effect On Women's Lecturer Performance In University of Muhammadiyah Surabaya, SSRG International Journal of Economics and Management Studies (SSRG-IJEMS),6(9), 48-55 
I. F.Segovia, B. Peidro, A.Fuentes, "Implementation of a food safety management system according to ISO 22000 in the food supplement industry: A case study", Food Control Journal,2014; 43: 28-34, https://doi.org/10.1016/j.foodcont.2014.02.042

C. E.María, L.S. Vijande, "Reasons and constraints to implementing an ISO 22000 food safety management system: Evidence from Spain". Food Control Journal, 2014;40: 50-57, https://doi.org/10.1016/j.foodcont.2013.11.032

L. Macheka, F. A. Manditsera, R.T. Ngadze, J. Mubaiwa, L. K. Nyanga, "Barriers, benefits and motivation factors for the implementation of food safety management system in the food sector in Harare Province, Zimbabwe". Food Control Journal, 2013;34: 126-131, https://doi.org/10.1016/j.foodcont.2013.04.019

F.I.Dwiantoro, "Pengaruh Gaya Kepemimpinan Tranformasional dan Tansaksional Tehadap Kinerja Organisasi Melalui Praktik TQM Pada PT. Pelayaran”. Jurnal Ilmu Manajemen, 2017; 05:1-14, https://jurnalmahasiswa.unesa.ac.id/index.php/jim/article/download/19175/17509+\&cd=4\&hl=jv\&ct= $\underline{\mathrm{clnk} \& \mathrm{gl}=\mathrm{id}}$

F.Rahim, V. P.K. Lengkong, L. O.H. Dotulong, "Pengaruh Kepemimpinan Transformational Dan Kepemimpinan Transaksional Terhadap Kinerja Karyawan Pada PT. PLN Wilayah Sulutenggo". Jurnal EMBA, 2018;4: $3503 \quad$-3512, https://ejournal.unsrat.ac.id/index.php/emba/article/viewFile/21623/21326

E.S.Ong, H. Ariwibowo, Isnawati, "Pengaruh Kepemimpinan Transformasional, Kepemimpinan Transaksional Dan Kebijakan Perusahaan Tentang Upah Pekerja Terhadap Produktivitas Kerja (Studi Pada PT "X" Di Surabaya)". Jurnal Jeksekutif, 2018;5: 334-335, https://jurnal.ibmt.ac.id/index.php/jeksekutif/article/view/200/168

N.S. Aqmarina, H.N. Utami, A. Prasetya," Pengaruh Kepemimpinan Transformasional Dan Kepemimpinan Transaksional Terhadap Kepuasan Kerja Dan Kinerja Karyawan ( Studi Kasus Pada Karyawan Hotel Gajah Mada Malang)". Jurnal Administrasi Bisnis,2016;35:164-173, http://administrasibisnis.studentjournal.ub.ac.id/index.php/jab/article/view/1382

R. Wahyuniardi, H.R. Nababan, "Pengaruh Kepemimpinan Transformasional Dan Budaya Organisasi Terhadap Kepuasan Kerja Serta Dampaknya Pada Kinerja Karyawan”, Jurnal Teknik Industri, 2018;19:118-226, https://doi.org/10.22219/JTIUMM.Vol19.No2.118-126

M.Birasnav, "Knowledge management and organizational performance in the service industry: The role of transformational leadership beyond the effects of transactional leadership", Journal of Business Research, 2014;67:1622-1629, https://doi.org/10.1016/j.jbusres.2013.09.006

A.Joshi, S.Kale, Sa.Chandel, D. K. Pal, "Likert Scale: Explored and Explained", British Journal of Applied Science \& Technology, 2015;7:396-403, https://pdfs.semanticscholar.org/38a7/5a7cc366dd963113c6923ac4a73c3286ab22.pdf

Williams, Gavin, "Structural Equation Modeling Methodes In Strategy Research: Application and Issue" Research Methodology in Strategy and Management (Research Methodology in Strategy and Management, Vol. 1), Emerald Group Publishing Limited, Bingley, 2004; pp. 303-346. https://doi.org/10.1016/S1479-8387(04)01111-7 